\title{
Loading and Distribution of Organic Materials in Maninjau Lake West Sumatra Province-Indonesia
}

\author{
Junaidi, Hafrijal Syandri* and Azrita \\ Department of Aquaculture, Faculty of Fisheries and Marine Science, Bung Hatta University Padang, Indonesia
}

\begin{abstract}
Research loading of organic material, total organic matter (TOM) and the water quality and its impact on the ecosystem of the lake was conducted in the year 2013. Organic load of waste floating net cages from 2001 to 2013 as much as $111,889.84$ tons with an average of as much as 9324.98 tons/year. Levels of total organic matter (TOM) in Koto Malintang station are 19.94 mg/l, Koto Kaciek 16.69 mg/l, Bayur 9.32 mg/l, Sigiran $14.10 \mathrm{mg} / \mathrm{l}$ and the outlet of the lake on Hydropower Intake $9.35 \mathrm{mg} / \mathrm{l}$. TOM accumulation in Maninjau Lake amounted to $10.59 \mathrm{mg} / \mathrm{l}$ or $53.10 \%$ of the incoming load from the floating net cages. The quality of the surface water dissolved oxygen at each side research showed almost the same conditions ranged from 5.70 to $6.77 \mathrm{mg} / \mathrm{l}$, except at a depth of 15 meters ranged from 3.26 to $4.12 \mathrm{mg} / \mathrm{l}$, $\mathrm{pH}$ ranges from 8-10, brightness ranges from 1.2 to $2.0 \mathrm{~m}$. Effect of organic matter accumulation has caused the status of heavily polluted lake water quality and mass mortality of fish in floating net cages every year.
\end{abstract}

Keywords: Maninjau lake; Floating net cages; Loading, Organic load; Water quality

\section{Introduction}

Maninjau Lake geographically in Agam District of West Sumatra Province Indonesia, an important role as a tourist venue, hydroelectric power, capture fisheries and aquaculture carp (Cyprinus carpio) and tilapia (Oreochromis niloticus) with a floating net cages. The potential of this lake as a medium for the cultured of carp with floating net was started in 1992 with a number of 64 units and production 96 tons [1]. In 2013 floating net cages have totaling to 16,210 units as much as 12,090 tonnes of fish production with a production value of USD 2.1726 billion [2]

Maninjau waters at this point in heavy eutrophic status [2] which is caused by contamination of organic material derived from the cultured of carp and tilapia with a system of floating net cages. Syandri et al. [3] stated that the supply of organic ingredients sourced from floating net cages is estimated at $24,750,000 \mathrm{~kg} /$ year, equivalent to $68,750 \mathrm{~kg} /$ day. This organic material decomposes completely if will provide inputs of nitrogen $(\mathrm{N})$ equal to $1,079,100 \mathrm{~kg} /$ year and phosphorus (P) of $123,750 \mathrm{~kg}$ per year. In Cirata Reservoirs West Java Province the input of organic material from the activity floating net cages in the form of nitrogen $(\mathrm{N})$ of $8,667,168 \mathrm{~kg} /$ year and phosphorus $(\mathrm{P}) 1,239,076 \mathrm{~kg} /$ year [4]. Kelly [5] states that solid wastes from floating net cages will accumulate with sediments in the bottom waters. Overhaul of the organic material in the water does not take place immediately and perfectly, the first process that occurs is the accumulation of organic material in bottom waters and during the reform process underway in bottom waters will occurs the use of oxygen in the layer maximum hipolimniom waters which resulted in anaerobic conditions resulting in a high residual metabolites. This study aims to analyze the loading of organic material from the fish farming activity floating net cages and their impact on water quality of Maninjau Lake.

\section{Methodology}

To determine the level of loading of organic matter derived from the activity floating net cages, analyzed data on the number of floating net cages from 2001 to 2013 are predicted in active use by $80 \%$ /year. The amount of feed from 2001 to 2008 are given three tonnes/units with twice the maintenance period/year, whereas from 2009 to 2013 feed given only 1.5 tons/units with maintenance once/year. This is due to the quality of water that is less support for fish culture and often the case mass mortality of fish so that the fish farmers are no longer able to cultured fish throughout the year. Fish production annually of the value predicted feed conversion ratio of 1.6.

Examples of sediment were taken at five stations in the waters of Maninjau Lake are Koto Malintang, Koto Kaciek, Bayur, Tanjungsani villages and outlet of the lake in Muko-Muko vilage (Figure 1). Sediment taken with Ekman Grab the size of $15 \times 15 \mathrm{~cm}^{2}$. Organic content was analyzed by the method of ashing in muffle furnace (temperature $600^{\circ} \mathrm{C}$ ) were previously treated with a strong acid to remove carbonates [6]. Water organic parameters determined from the levels of total organic matter (TOM), dissolved organic matter $(\mathrm{DOM})$ and particulate organic matter (POM) in the water the layer the euphotic region under floating net. TOM and DOM levels used titrimetric method $\mathrm{KMnO}$, $\mathrm{DOM}$ values obtained from water that has previously been mollipore filtered with filter paper (pore diameter of $0.45 \mu \mathrm{m}$ ), whereas the value POM obtained from the difference between the value of TOM and DOM.

Water quality was measured at five stations lake region is the water temperature, $\mathrm{pH}$, TSS, TDS, brightness, oxygen, $\mathrm{BOD}, \mathrm{COD}$, total $\mathrm{P}$, total $\mathrm{N}$ and electrical conductivity using the method [7].

\section{Results and Discussion}

The organic loading rate based on the number Maninjau floating net cages, fish production and the amount of feed are listed in Table 1. Organic

*Corresponding author: Hafrijal Syandri, Departement of Aquaculture, Faculty of Fisheries and Marine Science, Bung Hatta University Padang, Indonesia, Tel: 9175423212; E-mail: syandri_1960@yahoo.com

Received September 25, 2014; Accepted October 22, 2014; Published October 24, 2014

Citation: Junaidi, Syandri H, Azrita (2014) Loading and Distribution of Organic Materials in Maninjau Lake West Sumatra Province-Indonesia. J Aquac Res Development 5: 278. doi:10.4172/2155-9546.1000278

Copyright: () 2014 Junaidi, et al. This is an open-access article distributed under the terms of the Creative Commons Attribution License, which permits unrestricted use, distribution, and reproduction in any medium, provided the original author and source are credited. 
Citation: Junaidi, Syandri H, Azrita (2014) Loading and Distribution of Organic Materials in Maninjau Lake West Sumatra Province-Indonesia. J Aquac Res Development 5: 278. doi:10.4172/2155-9546.1000278

Page 2 of 4

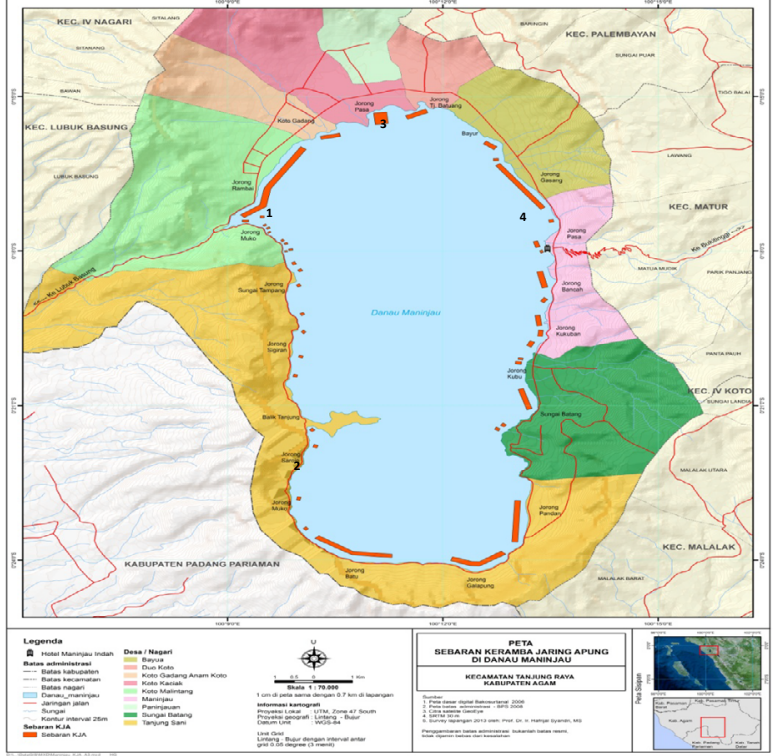

Figure 1: Map of Maninjau Lake, West Sumatera Province.

load of waste floating net cages from 2001 to 2013 in Lake Maninjau totaled 111889.84 tons with a load average of 9324.98 tons/year and the average load of 24.60 tonnes/day. The amount of organic waste each year fluctuates in line with the highest level of fish production and in 2008 reaching 43.31 tons/day. Load of organic waste in Maninjau Lake bigger than Cirata Reservoirs in West Java Province is 6556.20 tons/ year [8]. However, these differences give the same effect, namely the existence of a mass mortality cultured fish in floating net cages.

Levels of dissolved organic (DOM) look more dominant than the particulate organic (POM) in preparing total organic compounds (TOM) and DOM fractions showed a decrease in levels of the location of floating net cages to the outlet of the lake (Table 2).

According to Saunders in [9] in lake waters proportion of dissolved organic fraction is much higher than the particle. Sedimentation and mineralization processes thought to contribute to a decrease in the organic content in Maninjau Lake. Calm water conditions in the lake is to provide a process of sedimentation and mineralization take place is well. Dissolved organic components more susceptible to mineralization, whereas the component particles will experience sedimentation. Dissolved organic content (DOM) is more dominant than the particulate organic (POM) in the total organic produce (TOM) and DOM fraction levels were higher in deeper waters much

\begin{tabular}{|c|c|c|c|c|c|c|c|c|}
\hline \multirow[t]{2}{*}{ Year } & \multirow{2}{*}{$\begin{array}{l}\text { Number of } \\
\text { floating net } \\
\text { cages }\end{array}$} & \multirow{2}{*}{$\begin{array}{l}\text { Number of } \\
\text { productive } \\
\text { floating net } \\
\text { cages }(80 \%)\end{array}$} & \multicolumn{2}{|c|}{ Fish production (ton) } & \multicolumn{2}{|c|}{ Feed (ton) } & \multicolumn{2}{|c|}{ Organic waste (ton) } \\
\hline & & & $\mathrm{BB}^{1}$ & $\mathrm{BK}^{2}$ & $\mathrm{BB}^{3}$ & $\mathrm{BK}^{4}$ & Per year ${ }^{5}$ & per day \\
\hline 2001 & 3500 & 2800 & 10500.00 & 2625.00 & 16800.00 & 8400.00 & 5775.00 & 16.04 \\
\hline 2002 & 3608 & 2886 & 10822.50 & 2705.62 & 17613.00 & 8806.60 & 6100.98 & 16.94 \\
\hline 2003 & 3960 & 3168 & 11880.00 & 2970.00 & 19008.00 & 9504.00 & 6534.00 & 18.15 \\
\hline 2004 & 4316 & 3452 & 12945.00 & 3236.25 & 20712.00 & 10356.00 & 7120.00 & 19.78 \\
\hline 2005 & 4920 & 3936 & 14760.00 & 3690.00 & 23616.00 & 11808.00 & 8118.00 & 22.55 \\
\hline 2006 & 8955 & 7164 & 26865.00 & 6716.25 & 42984.00 & 21492.00 & 14775.75 & 41.05 \\
\hline 2007 & 9100 & 7280 & 27255.00 & 6806.25 & 43560.00 & 21780.00 & 14973.75 & 41.59 \\
\hline 2008 & 9450 & 7560 & 28350.00 & 7087.50 & 45360.00 & 22680.00 & 15592.50 & 43.31 \\
\hline 2009 & 9830 & 7864 & 14745.00 & 3686.25 & 23592.00 & 11796.00 & 8109.75 & 22.52 \\
\hline 2010 & 13129 & 10503 & 9846.56 & 2461.64 & 15745.00 & 7872.50 & 5410.86 & 15.03 \\
\hline 2011 & 15000 & 12000 & 11250.00 & 2812.50 & 18000.00 & 9000.00 & 6187.5 & 17.18 \\
\hline 2012 & 15860 & 12688 & 11895.00 & 2973.75 & 19032.00 & 9516.00 & 6542.25 & 18.17 \\
\hline 2013 & 16120 & 12896 & 12090.00 & 3022.50 & 19344.00 & 9672.00 & 6649.50 & 18.47 \\
\hline & \multirow{3}{*}{\multicolumn{2}{|c|}{$\begin{array}{l}\text { Information: } \\
\text { BB: wet weight } \\
\text { BK: dry weight }\end{array}$}} & \multicolumn{6}{|c|}{ Waste number from 2001 to 2013 (ton)=111.889,84 } \\
\hline & & & \multicolumn{6}{|c|}{ Avarage waste/year (ton) $=9324.98 \pm 3795.24$} \\
\hline & & & \multicolumn{6}{|c|}{ Avarage waste/day(ton) $=24.60 \pm 10.72$} \\
\hline
\end{tabular}

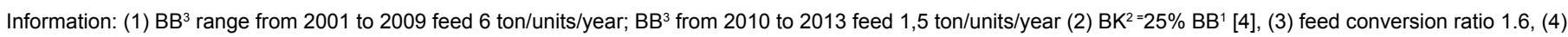
$50 \% \mathrm{BB}^{3}$ [4], 1991), (5) BK feed-BK fish

Table 1: Data of floating net cages, fish production, number of feed and waste organic prediction.

\begin{tabular}{|l|c|c|c|c|}
\hline \multirow{2}{*}{ Parameter } & \multicolumn{3}{|c|}{ Site location } \\
\cline { 2 - 5 } & Koto Malintang & Koto Kaciek & Bayur & Lake Outlet \\
\hline TOM $(\mathrm{mg} / \mathrm{l})$ & $19.01 \pm 0.80^{\mathrm{a}}$ & $16.33 \pm 0.30^{\mathrm{b}}$ & $9.12 \pm 0.24^{\mathrm{c}}$ & $9.31 \pm 0.10^{\mathrm{d}}$ \\
\hline DOM $(\mathrm{mg} / \mathrm{l})$ & $14.20 \pm 0.13^{\mathrm{a}}$ & $10.14 \pm 0.05^{\mathrm{b}}$ & $6.58 \pm 0.24^{\mathrm{c}}$ & $13.59 \pm 0.44^{\mathrm{e}}$ \\
\hline POM $(\mathrm{mg} / \mathrm{l})$ & $4.55 \pm 0.05^{\mathrm{a}}$ & $6.50 \pm 0.05^{\mathrm{b}}$ & $2.55 \pm 0.05^{\mathrm{c}}$ & $8.17 \pm 0.08^{\mathrm{e}}$ \\
\hline
\end{tabular}

Information: Avarage $\pm S D(n=3)$ with different superscript letters indicate significant differences $(p<0.05)$

Table 2: Level of TOM, DOM and POM on the water sample.

\begin{tabular}{|c|c|c|c|c|c|}
\hline \multirow{2}{*}{ Parameter } & \multirow{2}{*}{ Unit } & \multicolumn{4}{|c|}{ Site location } \\
\hline & & Koto Malintang & Koto Kaciek & Bayur & Sigiran \\
\hline C-Organic total & $\%$ & $57.14 \pm 0.25^{a}$ & $62.32 \pm 0.40^{\mathrm{b}}$ & $48.81 \pm 0.82^{c}$ & $52.25 \pm 0,40^{d}$ \\
\hline Total Nitrogen (N) & $\%$ & $1.68 \pm 0.08^{a}$ & $2.10 \pm 0.05^{\mathrm{b}}$ & $1.10 \pm 0.05^{c}$ & $1.34 \pm 0.10^{d}$ \\
\hline Total Phosphorus (P) & $\%$ & $0.23 \pm 0.03^{a}$ & $0.32 \pm 0.02^{\mathrm{b}}$ & $0.12 \pm 0.02^{c}$ & $0.16 \pm 0.04^{d}$ \\
\hline Total Potassium $\left(\mathrm{K}_{2} \mathrm{O}\right)$ & $\%$ & $0.21 \pm 0.03^{a}$ & $0.28 \pm 0.04^{b}$ & $0.06 \pm 0.01^{c}$ & $0.11 \pm 0.02^{\mathrm{d}}$ \\
\hline Zinc $(Z n)$ & $\mu \mathrm{g} / \mathrm{kg}$ & $296.27 \pm 1.90^{\mathrm{a}}$ & $310.58 \pm 9.87^{b}$ & $174.04 \pm 4.03^{c}$ & $237.52 \pm 3.47^{d}$ \\
\hline Lead $(\mathrm{Pb})$ & $\mu \mathrm{g} / \mathrm{kg}$ & $103.30 \pm 3.03^{a}$ & $106.36 \pm 2.00^{b}$ & $56.27 \pm 6.15^{c}$ & $61.71 \pm 5.12^{\mathrm{d}}$ \\
\hline
\end{tabular}

Information: Avarage $\pm S D(n=3)$ with different superscript letters indicate significant differences $(p<0.05)$

Table 3: The chemical composition of sediments in Maninjau Lake. 
activity floating net cages (Koto Malintang, Koto Kaciek and Sigiran).

DOM fractions showed a decrease in levels of many waters floating net cages towards the lake outlet (intake hydropower Maninjau). The data indicate the presence of an organic load allochtonus sourced from floating net cages activities. In the waters Koto Malintang the number of floating net cages obtained 3,768 bags TOM levels of $19.94 \mathrm{mg} / \mathrm{l}$ $\left(0.01994 \mathrm{~kg} \mathrm{~m}^{-3}\right)$. The waters Koto Kaciek the number of floating net cages 1,060 units, TOM levels obtained $16.69 \mathrm{mg} / 1\left(0.01669 \mathrm{~kg} \mathrm{~m}^{-3}\right)$. Whereas at the outlet of the lake (hydropower intakes) levels released TOM $9.35 \mathrm{mg} / \mathrm{l}\left(0.0935 \mathrm{~kg} \mathrm{~m}^{-3}\right)$. Based on the difference between the organic load in the location of floating net cages in the waters Koto Malintang and released at the outlet of the lake, then accumulated in the Maninjau Lake TOM was $10.59 \mathrm{mg} / \mathrm{l}\left(0.1059 \mathrm{~kg} \mathrm{~m}^{-3}\right)$ or $53.10 \%$ of the load sourced from floating net cages. In Cirata Reservoir TOM accumulation is $29.4 \%$ of the incoming load is sourced from floating net cages [8]. TOM level differences may be caused by differences in the morphology of the water retention time.

Maninjau has an area of $9737 \mathrm{ha}, 10,226 \times 10^{6} \mathrm{~m}^{3}$ water volume and water retention time of 25.05 years [2], Cirata Reservoir different from the vast volume of 6,200 ha and water volume are $2,165 \times 10^{6} \mathrm{~m}^{3}$ and

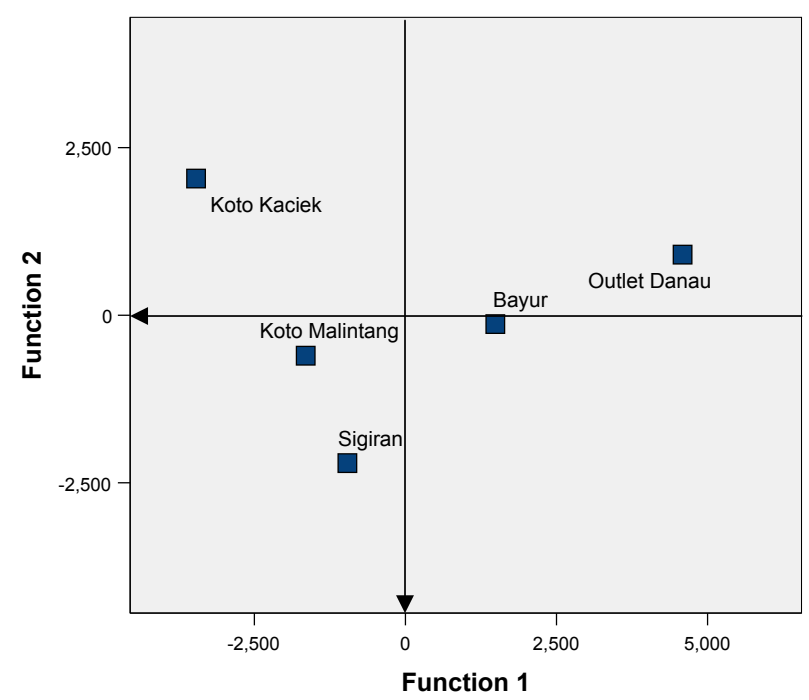

Figure 2: Water quality group in Maninjau Lake. ten months of water retention time. Syandri et al. [2] states that the difference of water area, water volume and water retention time in a body of water, which contained activity floating net cages will give the same effect, namely the existence of mass fish deaths. Syandri [3] states that the mass mortality of fish cultured with floating net cages as much as 950 tons have occurred in December and the year 2009 amounted to 1,350 tons [10]. The chemical composition of bottom sediments in floating net cages at each side research presented in Table 3 .

The dynamics of Total Phosphorus (TP) and Total Nitrogen (TN) in sediments will be affected by the activities of various biota at the bottom of the lake, so that the elements of sediment TP and TN as shown in Table 4 also correlated with temperature, $\mathrm{DO}, \mathrm{pH}$, and other compounds. The amount of sediment in Lake Maninjau is sourced from waste floating net cages predicted for thirteen years approximately $111,889.84$ tons last year, because the area is much shallower and shallower which resulted in more turbid waters. Suspected that the sediment resuspension process can result in reduction of light penetration and increase the quantity of particles dissolved in the waters. With increasing organic load can be predicted oxygen uptake by the sediment will be more than $85 \%$ so it appears anoxic conditions.

Accumulation of organic matter in the sediments is often followed by the enrichment of waters, especially with increasing orthophosphate. According to [5] that the orthophosphate compounds are released from the sediment diffuses into the upper layers that can directly be used by the plant components such as phytoplankton. Effendi [11] states that orthophosphate is a form of phosphorus that can be used directly by aquatic plants such as Eichornia crassipes.

\section{Water quality}

Water quality parameters in Maninjau Lake (Table 4) and significantly different $(p<0.05)$ between the research side (Figure 2$)$. Dissolved oxygen in surface waters each station showed almost the same conditions ranged from 5.70 to $6.77 \mathrm{mg} / \mathrm{l}$, except at a depth of 15 meters ranged from 3.26 to $4.12 \mathrm{mg} / \mathrm{l}$. Lukman and Hidayat [8] states in Maninjau in December 2008 and January 2009 dissolved oxygen ranged from 0.8 to $7.84 \mathrm{mg} / \mathrm{l}$. According to [9] fluctuations of oxygen in the water affect the occurrence of reduction and oxidation processes which are directly related to the formation of ammonia, nitrite and nitrate. Dissolved oxygen levels were measured in this study was quite high at the surface of the water, it is supported by the condition of the waters of Lake Maninjau fairly broad and open in supporting the development of autotrophic. Temperatures ranging from $27^{\circ} \mathrm{C}$ to $28^{\circ} \mathrm{C}, \mathrm{pH} 8$ to 10 , almost equal to the results of research [12] ranged

\begin{tabular}{|c|c|c|c|c|c|}
\hline \multirow{2}{*}{ Parameter } & \multicolumn{5}{|c|}{ Site location } \\
\hline & Koto Malintang & Koto Kaciek & Bayur & Outlet Danau & Sigiran \\
\hline Temperatures $\left({ }^{\circ} \mathrm{C}\right)$ & $27.66 \pm 0.57^{a}$ & $27.33 \pm 0.57^{a}$ & $28.00 \pm 0.00^{\mathrm{a}}$ & $26.66 \pm 0.57^{b}$ & $26.66 \pm 0.57^{b}$ \\
\hline $\mathrm{pH}$ & $10.00 \pm 0.00^{\mathrm{a}}$ & $10.00 \pm 0.00^{a}$ & $9.00 \pm 0.00^{\mathrm{b}}$ & $9.3 \pm 0.28^{c}$ & $9.00 \pm 0.00^{b}$ \\
\hline TSS (mg/l) & $14.35 \pm 0.40^{\mathrm{a}}$ & $16.44 \pm 0.04^{b}$ & $17.03 \pm 0.07^{c}$ & $4.19 \pm 0.03^{d}$ & $20.45 \pm 0.02^{\mathrm{e}}$ \\
\hline TDS (mg/l) & $33.08 \pm 0.11^{\mathrm{a}}$ & $26.73 \pm 0.03^{b}$ & $20.25 \pm 0.02^{c}$ & $9.77 \pm 0.03^{d}$ & $39.69 \pm 0.02^{\mathrm{e}}$ \\
\hline Brightness (m) & $2.00 \pm 0.00^{\mathrm{a}}$ & $1.19 \pm 0.17^{b}$ & $1.93 \pm 0.11^{\mathrm{a}}$ & $2.00 \pm 0.00^{\mathrm{a}}$ & $1.29 \pm 0.03^{c}$ \\
\hline $\mathrm{O} 2(\mathrm{mg} / \mathrm{l})$ of water surface & $6.10 \pm 0.04^{a}$ & $6.24 \pm 0.02^{b}$ & $6.77 \pm 0.02^{c}$ & $6.36 \pm 0.03^{d}$ & $5.73 \pm 0.03^{e}$ \\
\hline $\mathrm{O} 2(\mathrm{mg} / \mathrm{l})$ a depth of $15 \mathrm{~m}$ & $3.69 \pm 0.04^{a}$ & $3.24 \pm 0.04^{b}$ & $4.12 \pm 0.02^{c}$ & $4.89 \pm 0.03^{d}$ & $3.96 \pm 0.01^{\mathrm{e}}$ \\
\hline $\mathrm{BOD}_{5}(\mathrm{mg} / \mathrm{l})$ & $2.03 \pm 0.02^{\mathrm{a}}$ & $2.74 \pm 0.01^{b}$ & $2.13 \pm 0.03^{c}$ & $2.60 \pm 0.03^{d}$ & $2.98 \pm 0.03^{e}$ \\
\hline $\operatorname{COD}(\mathrm{mg} / \mathrm{l})$ & $30.50 \pm 0.02^{\mathrm{a}}$ & $47.79 \pm 0.02^{\mathrm{b}}$ & $16.11 \pm 0.05^{c}$ & $8.91 \pm 0.02^{\mathrm{d}}$ & $24.05 \pm 0.04^{\mathrm{e}}$ \\
\hline Total P (mg/l) & $0.49 \pm 0.03^{a}$ & $0.63 \pm 0.03^{b}$ & $0.57 \pm 0.02^{\mathrm{a}}$ & $0.54 \pm 0.04^{a}$ & $0.62 \pm 0.02^{\mathrm{b}}$ \\
\hline Total N (mg/l) & $1.076 \pm 0.02^{\mathrm{a}}$ & $1.111 \pm 0.00^{\mathrm{a}}$ & $1.373 \pm 0.35^{\mathrm{a}}$ & $1.563 \pm 0.03^{b}$ & $1.189 \pm 0.10^{a}$ \\
\hline $\mathrm{DHL}\left(\mathrm{ms} / \mathrm{cm}^{-1}\right)$ & $47.47 \pm 0.03^{a}$ & $39.86 \pm 0.03^{b}$ & $33.66 \pm 0.03^{c}$ & $23.18 \pm 0.01^{d}$ & $45.33 \pm 0.03^{e}$ \\
\hline
\end{tabular}

Information :Avarage $\pm S D(n=3)$ with different superscript letters indicate significant differences $(p<0.05)$

Table 4: Water quality parameters Maninjau waters in July 2013. 
Citation: Junaidi, Syandri H, Azrita (2014) Loading and Distribution of Organic Materials in Maninjau Lake West Sumatra Province-Indonesia. J Aquac Res Development 5: 278. doi:10.4172/2155-9546.1000278

from 7.01 to 10.29 that characterize wet waters. This lake productivity is high, indicated by the brightness ranges from 1.2 to $2.0 \mathrm{~m}$. In contrast to Toba Lake with relatively low levels of productivity with brightness ranging from 7 to $15 \mathrm{~m}[5,13]$.

TP levels in surface waters in July 2013 ranged from $0.49 \pm 0.03 \mathrm{mg} / \mathrm{l}$ to $0.63 \pm 0.03 \mathrm{mg} / \mathrm{l}$ and TN levels ranged from $1.076 \pm 0.02$ to $1.563 \pm$ $0.03 \mathrm{mg} / \mathrm{l}$. TP and TN levels higher detected in waters crowded floating net cages in the waters of the Koto Kaciek and Sigiran, including the waters of the lake outlet (intake hydropower Maninjau). [14] states in Lake Toba fish feeding activity in floating net cages is suspected to be a source of nutrient elements input TN and TP.

\section{Acknowledgment}

Thanks to the Directorate of Research and Community Service (DP2M) Directorate General of Higher Education Ministry of Education and Culture which has provided research funding through the Excellent Research Universities 2014 and also thank to reviewers at JARD for valuable criticism of the manuscript.

\section{References}

1. Syandri $H$ (2003) Cages culture and problems in Maninjau Lake, West Sumatra Province. J Fisheries and Maritime Affairs 8: 74-81.

2. Syandri H, Junaidi, Azrita, Yunus T (2014) State of Aquatic Resources Maninjau Lake West Sumatra Province-Indonesia. J Ecology and Environ Sci 1: 109-113.

3. Syandri $H$ (2004) The use of asang fish (Osteochilus vittatus) and tawes fish (Puntius javanicus) as an agent of biological in Maninjau Lake. J Nature Indonesia 6: 87-91.
4. Garno YS, Adibroto TA (1999) National Seminar and Workshop on Management and Utilization of Lake and Reservoir.

5. Kelly LA (1992) Dissolved Reactive Phosphorus Release from Sediments beneath a Freshwater Cage Aquaculture Development in West Scotland. Hydrobiologia 235/236: 569-572.

6. Buchanan JB, Kain JM (1984) Measurement of the Physical and Chemical Environment.

7. Amrican Public Health Association (1995) Standard Methods for Examination of Water and Wastewater. APHA Washington, USA

8. Lukman, Hidayat (2001) Loading and distribution of organic matter in Cirata Reservoir. Journal of Environmental Technology 2: 129-135.

9. Wetzel RG (1983) Limnology.

10. Nasution Z, Sari YD, Huda HM (2011) Aquaculture in Lake Maninjau: Anticipation Handling Policy Impact Mass death of fish. Journal of Social Policy Economics and Fisheries 1: 19-31.

11. Sulawesty F, Sutrisno A, Hamdani, Triyanto (2011) Water quality conditions in the area of fish farming in floating net cages in Maninjau lake. Limnotek 18: 38-47.

12. Effendie $\mathrm{H}$ (2003) Assessing the quality of the water resource management and aquatic environments.

13. Lukman (2011) National Seminar on Management of natural resources and local knowledge-based environment.

14. Nomosatryo S, Lukman (2011) The availability of nutrients nitrogen (N) and phosphorus $(P)$ in Toba Lake, North Sumatra Province. Limnotek 18: 127-137. 